\title{
FUNKTSIONAALSEMANTILINE VÄLI \\ KUI MODAALTÄHENDUSTE LIIGITAMISE JA KEELTE VÕRDLEMISE ALUS
}

\author{
Pille Eslon \\ Tallinna Ülikool
}

Kokkuvõte. Funktsionaalsemantiline väli on objektide klassifitseerimise ja võrdlemise universaalne vahend, mida saab kasutada nii ühe keele piires kui ka tüpoloogilises plaanis. Et välja konstrueerimise aluseks on loomulikud mõisteseosed, mitte grammatilised kategooriad ja lausesüntaks, siis sobib väli liigituste loomiseks, sh artiklis kirjeldatud modaaltähenduste semantiline hierarhia, võimaldades täpsustada ja seletada ka mõningaid traditsioonilise keelekäsitluse raskuspunkte, näiteks tõeväärtushinnangu ambivalentsust. Modaalsuse välja konstrueerimiseks olen valinud tautoloogiliste ehk suletud ringide meetodi (ld idem per idem) ja semantilised hierarhiad. Semantilistes määrangutes võimaldab tähenduskomponentide lähedus-kaugus kombata leksikaalsemantilis(t)e rühma(de) piire, konstrueerida leksikaalsemantilisi mikrovälju ning neid omavahel siduda. Mõisteseoste üldistamisel olen modaalsuse funktsionaalsemantilise välja puhul kasutanud dialektilise loogika seadusi, mis aitavad leida objekti olulisi tunnuseid. Paigutatuna süntagmaatilisele ja paradigmaatilisele teljele, saab tunnuste ristumisest struktuur, mis on sobiv modaalliigituste loomiseks ja objekti süsteemseks kirjeldamiseks. Artiklis toon näiteid, mille põhjal saab järeldada, et ühe või teise modaaltähenduse väljendamisel on vene ja eesti keeles kasutusel lekseemide, vormide ning süntaktiliste struktuuride kindlad kooskasutusmallid, mille leksikaalsemantiline ja morfosüntaktiline varieerumine on piiratud. Keeliti esineb siin osalist või täielikku lahknevust, analoogiat ja kokkulangevusi.

Märksõnad: funktsionaalsemantiline väli, modaalsus, vene keel, eesti keel

DOI: http://dx.doi.org/10.12697/jeful.2016.7.2.02

\section{Sissejuhatus}

Erinevate nähtuste liigitamine ja kirjeldamine tugineb võrdlusele: iga üksikobjekt on määratud teiste objektide suhtes, iga valim on kirjeldatud üld- ja alamkogumi(te) suhtes. Lingvistikas on võrdlemine loomulik analüüsimeetod, mis võimaldab leida objekte eristavaid tunnuseid, neid defineerida ja liigitusi luua. Võrdluses tulevad esile seosed lingvistiliste 
objektide vahel, nende kombineerimise võimalused ja funktsionaalne potentsiaal, universaalsed ning spetsiifilised kasutusmustrid, keeltevahelised sümmeetria-, asümmeetria- ja analoogiaseosed jne.

Kuigi keeled jm lingvistilised võrdlusobjektid, nt süsteemid, struktuurid, lekseemid, vormid, paradigmad, süntagmad, kasutusmustrid erinevad, saab neid semantiliste tunnuste alusel edukalt võrrelda. Erinevate võrdlusmudelite ja arvutilingvistiliste rakenduste loomisel tuginetakse laialdaselt semantikale, kognitiivsemantilistele ja loogilistele hierarhiatele (nt Luuk 1999, 2008, 2010, K. Õim 2003, 2005, 2007, Tragel 2001, Tragel ja Veismann 2008), üldistatud semantilistele kategooriatele, mille piiritlemisel "on arvestatud ka argumentstruktuuri (konstruktsiooni) eripärasid" (Habicht ja Tragel 2014: 829-830), grammatiliste kategooriate, kategoriaalsete tähenduserisuste ning funktsionaalsemantiliste kategooriate põimumisele eri keeltes (nt Kehayov 2004a, 2004b, 2008), semantilisele kaardistamisele (nt van der Auwera ja Plungian 1998, Haspelmath 2003, van der Auwera, Kehayov ja Vittrant 2009), seostele lekseemide semantiliste struktuuride vahel Wordneti sõnastikes (Orav ja Vider 1998, Vider 2001, Vider ja Orav 2005, Orav jt 2011), mõistepuu ja mõisteartiklite struktuurile fraseologismide elektroonilises alussõnastikus (K. Õim ja A. Õim 2011: 845 jj) jm.

Siinses artiklis tuginen funktsionaalsemantilise välja mõistele Aleksandr Bondarko käsitluses (nt 1983: 26-27, 32-33, 40-53, 2002: 309-318), kuna tegu on integraalse kirjeldusega, kus väljad, nt aspektuaalsus, temporaalsus, personaalsus, modaalsus (vt Bondarko 1990: $59 \mathrm{jj}$ ), on omavahel seotud mikro- ning makrosüsteemideks. Soostun mööndusega, et funktsionaalsemantiliste väljade, nagu ka kategoriaalsete tähenduste piiritlemine on teatud määral interpretatiivne, sest lingvistikateadmiste teoreetilise üldistusena sõnastatud abstraktsed mõisted haaravad vaid teatud semantilisi aspekte. See ei tähenda, nagu puuduks võimalus keele kohta adekvaatsemaid andmeid saada. Näiteks lisab teavet keelesisene ja keeltevaheline sünonüümne/mittesünonüümne varieerumine (vt Bondarko 1992: 6 jj). Sellistel lausetel nagu Me juba arutasime seda küsimust, See küsimus on meil arutatud, Seda küsimust sai arutatud on sama sisu, kuid erinevad keelelised võimalused selle väljendamiseks ehk sisu interpreteerimiseks. Eriti iseloomulik on see predikatiivsetele kontekstitundlikele kategooriatele.

Siinses artiklis lähtun põhimõttest, et semantilised määrangud ja semantilised tüpoloogiad peegeldavad leksika ning grammatika koosmõju

1 Vt http://www.folklore.ee/justkui/sonastik/. Vaadatud 12.09.2016. 
tekstis. Rakendan seda seisukohta modaalsuse semantilise välja piiritlemisel, aluseks hierarhilised semantilised seosed kolme modaaltähendusliku lekseemi võimalus, soov ja vajadus, nende tuletiste ning sünonüümide tähenduskomponentide ja tähendusstruktuuride vahel (Eslon 1998). Sellest on tingitud ka kasutusnäidete valik. Eesmärk on kirjeldada modaalsuse funktsionaalsemantilist välja keelest lähtuvalt, siinses uurimuses koostatuna vene keele sõnatähenduste põhjal ja võrrelduna eesti keelega, samas abstraheerides konkreetsetest keelelistest tähendustest, mis võimaldab semantiliste opositsioonide ja nende neutraliseerumise alusel esile tuua modaalsuse semantilise hierarhia. Seda hierarhiat võib kasutada näiteks kõrvuti van der Auwera ja Plungiani (1998), EKG II (1993: 182-191) või Ellen Uuspõllu (1989)² liigitustega, et võrrelda modaalsuse väljendusvahendeid nii eri keeltes ja allkeeltes kui ka diakroonilise ja paikkondliku varieerumise puhul.

Kirjeldades funktsionaalsemantilisi välju, näitab Bondarko, et universaalsete mõistekategooriate semantilist hierarhiat saab edukalt kasutada semantilistes tüpoloogiates ja tüpoloogilistes uurimustes tervikuna (Bondarko 1983: 76-96). Erinevalt traditsioonilisest bilateraalsest käsitlusest tõi näiteks aspektuaalsuse väljendusvahendite võrdlus funktsionaalsemantilise välja alusel vene ja eesti keele vahel esile rohkesti analoogiat, vähem sümmeetriat ja vähe asümmeetriat (vt Eslon 2006: 22-24), millel on oluline tähendus kõrvutava grammatika ja kakskeelsete sõnastike koostamisel, tõlkimisel ja keeleõppes. Teisalt ilmnes, et vene keeles on aspektuaalsuse funktsionaalsemantilise välja tuumaks nii verbi aspekti ajavormid kui ka süntaktilised struktuurid, mis on seotud kindlat liiki kontekstidega, kus a) aspektid on vastandatud ja kasutada saab vaid ühte kahest vormist, näiteks kui jutt on konkreetsest faktist, siis perfektiivse aspekti oleviku-tuleviku, harvem mineviku vormi või infinitiivi - Ветер неожиданно затих “Äkitselt tuul vaibus'; kui jutt on protsessist või seisundist, siis imperfektiivse aspekti oleviku ja mineviku vormi - Он лежит и читает книгу 'Ta on pikali ja loeb raamatut'; b) samas aspektuaalses situatsioonis verbi aspekt varieerub ning kasutada saab mõlemat vormi, kuid tähendus erineb, nt infiniitlauses нам всем пропадать/nропасть * 'me kõik hukkume / oleme hukule määratud' paratamatuse tähenduses, kus imperfektiivse aspekti

2 Otsene eeskuju on olnud Heikki Kangasniemi modaalsuse liigitus: dünaamiline (võimalikkus, vajalikkus ja selles väljenduv implitsiitne hinnang), deontiline (käsk, keeld, palve, soovitus jm) ja epistemoloogiline (modaalne hinnang, tõeväärtushinnang). Kolmikjaotusse ei ole sobitunud tahteavaldus, positiivne/negatiivne hinnang ja volitamine (vt Kangasniemi 1992). 
vorm tähistab eelseisva sündmuse paratamatust ja perfektiivse aspekti vorm pöördumatust; c) aspektivastandus neutraliseerub ja esiplaanile tulevad pragmaatilised tähendused, nt вы едете / поедете в деревню? 'kas te sõidate maale?' - kõneleja ootab oma küsimusele jah- või eivastust, mis pole seotud aspektilisusega. Verbi aspekti ajavormidega võrreldes on kõneviis ja tegumood taustkategooriad.

Erinevalt vene keelest on eesti keeles aspektuaalsuse funktsionaalsemantilise välja tuumaks verbi leksikaalgrammatilised klassid (aspekt-, perfektiiv- ja imperfektiivverbid), analüütilised perifrastilised verbid (ühend- ja väljendverbid, ahelverbid); verbipartiklid, perifrastilised verbivormid, nagu hakkab (saab) tegema-tulevik ja on tegemas-progressiiv (põhjalik kokkuvõte eesti keele aspektilisusest vt Erelt 2013: 71 jj) ning ajavormid (Metslang ja Tommola 1995; võrdluses vene keelega Eslon ja Pihlak 1991). Uurimused näitavad, et tänapäeva eesti keeles viib väiksemgi tähendusnihe rektsioonimuutusteni, perfektiiv- ja imperfektiivverbe kasutatakse aina laiemalt aspektverbide funktsioonis (vt Vaiss 2004), mistõttu lause aspektuaalsuse tõlgendamisel on järjest suurem osakaal infostruktuuril. See tingib olukorra, kus aspektuaalsete tähenduste edastamine objektikäände abil on vaid üks võimalikest, kuid mitte olulisim funktsioon, sest käändevariatiivsus sõltub paljude leksikaalsemantiliste ja morfosüntaktiliste faktorite koosmõjust lause infostruktuuriga. Eesti keele objektikäänete varieerumine on olnud ajas laineline, minetamata oma soomeugrilist olemust (määratus/määramatus), seotud keele sisemiste arengutega, nagu paradigma lühenemine morfofonoloogiliste protsesside mõjul ja vormihomonüümia laienemine (vt Eslon ja Õim 2010: 69, 79, 85). Anne Tamm on oma üldistavas uurimuses arvestanud mitme relevantse semantilise tunnusega, mis võimaldavad esile tuua seoseid verbi leksikaalse semantika, transitiivsuse/ intransitiivsuse, objekti käändevaliku ja lause argumendistruktuuri vahel (Tamm 2012: 11-12), ent ka selle põhjaliku kirjelduse alusel on selgelt näha, et lause aspektuaalsuse tõlgendamise kesksed vahendid on verbi leksikaalgrammatilised rühmad ja ajavormid (nt oleviku-tuleviku vormihomonüümia, oleviku vastandus mineviku liht- ning liitvormidele, täismineviku-lihtmineviku vastandus, lihtmineviku-täisminevikuennemineviku varieerumine samaaegsete ja järjestikuste tegevuste või sündmuste kirjeldamisel). Kõneviisi kategooria kuulub samuti nagu vene keeles aspektuaalsuse funktsionaalsemantilise välja perifeeriasse.

Siinse funktsionaalsemantilise välja kirjelduse seostan avarama hinnangu mõistega, mis hõlmab lisaks lause sisu modaalsele hinnangule tegelik/võimalik ka tõeväärtushinnangut, pragmaatilist väärtushinnangut 
hea/halb ning emotsionaalset hinnangut (vt EKG II 1993: 182-191). Piir nimetatud aspektide vahel kulgeb semantika, grammatika ja pragmaatika piirimail, mis viitab selgesti predikatiivsete kategooriate interpretatiivsele olemusele. Näiteks ilmaprognoosi neutraalse sõnastuse põhjal tuleb päikeseline ilm 'будет хорошая погода' või on oodata päikeselist ilma 'ожидается хорошая погода' saab suure tõenäosusega väita, et homme on ilus ilm, see on reaalselt võimalik. Seda asjade seisu tõlgendatakse ennekõike kui otsest või varjatud hinnangut (hea/halb uudis), mis hakkab adressaati mõjutama, suunates tema seisukohtade ja arusaamade kujunemist. Sedalaadi leksikaalsemantiliselt ja morfosüntaktiliselt neutraalsed sõnastused on üks keelelise mõjutamise vahendeid (tekstipragmaatiline aspekt). Verbi semantika ja ajavormidega (tuleb, on oodata) edastatud modaalhinnang (antud juhul reaalne võimalikkus) on pragmaatilise hinnanguga võrreldes sekundaarne. Info tõeväärtuse astet märgivad modaalsed abisõnad, nagu ilmselt, tõenäoliselt, arvatavast $i$, vist (homme tuleb ilmselt (arvatavasti, tõenäoliselt, vist) päikesepaisteline ilm 'завтра, по всей вероятности (вероятно), будет солнечная погода'), mis vahendavad kõneleja oletust modaaladverbide abil, mitte predikaadiga. Niisiis võib samalaadsete sõnastuste modaalhinnangut interpreteerida erinevates aspektides (reaalne võimalus - reaalsushinnang, tõenäosus - tõeväärtushinnang) ja teiste hinnangu liikide suhtes (pragmaatiline väärtushinnang - hea/halb uudis, emotsionaalne - hea uudis teeb meele rõõmsaks, halb kurvastab), seostada seda predikaadi $\mathrm{ja} / \mathrm{või}$ lause modaalsusega. Tekstikasutuses on need aspektid põimunud, mõjutades otseselt või kaudselt hinnangute sõnastamist ja selle toimet seisukohtade kujundamisel.

\section{Modaalsuse väli}

Modaalsuse väli rajaneb semantiliste määrangute lähedusel, mille tuvastamiseks olen võrrelnud kolme modaaltähendusliku lekseemi võimalus, soov ja vajadus, nende tuletiste ja sünonüümide sõnastikuseletusi tautoloogiliste ehk suletud ringide meetodil. Selleks olen sõna tähendusstruktuuri alusel otsinud mõisteseoseid, kus sõna-1 on defineeritud sõna-2 vahendusel ja vastupidi, nt mõeldav (sõna-1) on see, mis on võimalik (sõna-2) ja vastupidi - võimalik (sõna-2) on see, mis on mõeldav (sõna-1). Tekib suletud ring, mis näitab mõeldava ja võima$l i k u$ vahetut mõisteseost. Mida abstraktsem on tähenduskomponent, seda kitsam on ring teatud sõnade semantiliste määrangute vahel ning 
seda tõenäosem on, et tegu võib olla modaalsuse makro- või mikrovälja semantilise dominandiga (nt võimalikkus ja potentsiaalsus). Seoseid semantiliste määrangute vahel olen interpreteerinud dialektilise loogika (vastandtunnuste dialektika), abstraktsiooni tasandi (mõisteline $>$ kategoriaalne $>$ konkreetne) ja ettemääratuse-tahteavalduse skaalal, mis seostub pigem van der Auwera ja Plungiani (1998: 82) võimalikkusevajalikkuse skaalaga (vt ka Klettenberg 2007: 376, Mandra 2007) kui modaalsusruudu paratamatuse-võimalikkuse-juhuslikkuse skaalaga. Semantilise hierarhia kirjelduses kasutan süsteemsuse loomiseks paradigmaatilist ja süntagmaatilist telge, mille piires vaatlen abstraktseid semantilisi tunnuseid nii erinevates kombinatsioonides, erinevatel tasanditel kui ka telgede ristumispunktides samaaegselt. See võimaldab esile tuua universaalsusele pretendeeriva semantilise tüpoloogia.

Funktsionaalsemantilise välja mõisteseoste kirjeldamisel olen kasutanud eesti ja vene keele leksikograafilisi allikaid (Jevgenjeva 1985, 2003, EKSS, Õim 1995, Eesti keele tesaurus³). Näiteid otsisin korpustest ${ }^{4}$ ja grammatikatest (EKG II 1993, Russkaja grammatika 1980), aluseks välja semantiline hierarhia. Artiklis olen neid lühendanud ja mugandanud oma keeletunnetusele tuginedes.

Modaalhinnangu objekt on nähtus või sündmus, mille tuumaks on kellegi-millegi tegevus, seisund, olemus või mingi nähtus. Dialektilisest loogikast lähtuv esmane modaalne vastandus avaneb tegeliku/võimaliku skaalal. Võimalikku nähtust saab hinnata reaalse/mittereaalsena ja realiseeritava/mitterealiseeritavana (süntagmaatiline telg). Teine modaalsuse skaala kujuneb millegi (mitte)ilmnemise, (mitte)toimimise ja (mitte)kehtimise asjaolude põhjal, mis mõjutavad sündmuse reaalsust/mittereaalsust ja realiseeritavust/mitterealiseeritavust otseselt või kaudselt (paradigmaatiline telg). Ühelt poolt hinnatakse sündmuste kulgu tingituna objektiivsetest/subjektiivsetest asjaoludest (reaalsed olud, normid, vajadused, tahteavaldus) ning teisalt ettemääratuna (determineeritus). Kahe hinnanguskaala ristumispunktid toovad esile modaalsuse semantilise tüpoloogia.

Reaalse/mittereaalse ja realiseeritava/mitterealiseeritava vastanduse neutraliseerumist saab tõlgendada kaheti. Kuna eitus on mõiste mahult jaatusest avaram, sisaldades viimast, siis on mittereaalne ja mitterealiseeritav samaaegselt nii opositsiooni vastandliige kui ka vastandust neutraliseeriv mõiste. Neutraliseerumine võib toimuda ka kolmanda,

3 Vt http://www.filosoft.ee/. Vaadatud 11.05.2016.

4 Vt www.keeleveeb.ee (Tasakaalus korpus) ja www.ruscorpora.ru/. Vaadatud 11.05.2016. 
ülesema mõiste kaudu, milleks nimetatud kahe vastanduse puhul on potentsiaalsus: saame järeldada ja väita, et miski on potentsiaalselt reaalne ja mittereaalne, potentsiaalselt realiseeritav ja mitterealiseeritav. Seega kuulub potentsiaalsuse mõistele modaalsuse semantilise välja interpreteerimisel keskne koht, kuna see ühendab omavahel kaks modaalse hinnangu aspekti: reaalsushinnangu ja realiseeritavushinnangu, mille sisu konkretiseerub mõiste tasandil.

Reaalsushinnang tugineb ühelt poolt teadmisele ja teisalt oletusele. Esimesel juhul hinnatakse seda, kas miski on lubatud, kas kellelgi on õigus (lubatud) midagi teha (nt lastele sissepääs poole hinnaga, üliõpilased tohivad (võivad, saavad) töötada täiskoormusega, neil on õigus (luba, voli) töötada poole kohaga, lapsed peavad koolis käima, võlg tuleb tagastada, võlg on võora oma), kas miski on keelatud, kellelgi pole õigust (voli) midagi teha (nt murul käimine keelatud, siin ei suitsetata (ei tohi suitsetada), see pole suitsetamise koht), kas midagi pole soovitatav teha, sest on vale, kahjulik, pole soositud (nt rämpstoit on ebatervislik, alkohol on vastunäidustatud, haigestumist oleks hea (tuleks) vältida, töötasu on soovitav üle kanda igal reedel, vaata ettevõid kukkuda), kas miski toimib subjekti tahtest sõltumata, nagu looduse ja inimühiskonna seaduspärasused (nt nõgesed kõrvetavad, hundid on kiskjad, metallid ei purune, vesi keeb temperatuuril $100^{\circ} \mathrm{C}$ ), või on tegu üldistatud kogemusega (nt küll inimesed aru saavad, on, kust vastuseid saada, julge hundi rind on rasvane, saatuse eest pole pääsu).

Teisel juhul tugineb reaalsushinnang oletusele (sünonüümid oletamine, hüpotees), mis tähistab millegi (mitte)mõeldavust kui (mitte)võimalikkust, (mitte)vajalikkust (nt arvatakse, et ta külmus surnuks; kardan, et tõlge on lohakas; mulle näib, et keegi ei saanud millestki aru; kahtlen otsuse õigsuses ja vajalikkuses; ei näe (olevat) põhjust; ei tunneta (tunnetan) vajadust mida teha). Langetatud otsus võib mõjutada või mitte mõjutada sündmuste arengut. Ühelt poolt võib olla tegu indiviidist sõltumata kulgevate protsesside äratundmisega, mille aluseks on tõekspidamised, reaalsed faktid ja sündmused (nt ta pidi olema sellest teadlik, asjatundjate sõnul olevat tehtud järeldused tõesed (väärad), faktid kinnitavat olukorra tõsidust, see ei vasta tõele, kuna ..., pü̈̈an suu pidada ja edasi teenida, headus tõmbab ligi, kadedus teeb lolliks, tuleb suur sõda), teisalt indiviidi vajaduste, soovide ja tahteavaldusega viisakast märguandest, soovitusest, hoiatusest, soovist või palvest (nt laps tahab juua, tal on janu, anna mulle klaas vett, kõik vajavad mõistmist, võtke asja rahulikult, pane uks kinni, olgem üksteise suhtes sallivamad, võtame üksteisel käest, ema käskis marju korjata) kategoorilise 
nõudmise, hädavajalikkuse ja vältimatuseni (nt vasta kohe, korista oma käed, jutud jätta, vaikust, teie dokumendid, ära vehi kätega, kutsuge viivitamatult arst, püsti - kohus tuleb, mitte suitsetada, on kästud suu pidada, kuhugi te ei lähe, ole vait ja kuula, ei saa üle ega ümber). Tunnetatud tõdemus ja indiviidi tahteavaldus a) tingivad, määravad, determineerivad või ei tingi ega määra ning b) soosivad või ei soosi millegi (mitte)toimimist.

Toimimise sisemiseks eelduseks on asjade ja isikute omadused, mis rakenduvad või lubavad (võimaldavad) teistel neid rakendada teatud tingimustel ja tingimustes. Omaduse mõiste vahendab reaalsus- ja realiseeritavushinnangut, sidudes need omavahel. Asjadel ja nähtustel on omadused, isikutel aga on võime. Mõlema mõiste ühissünonüüm on potentsiaal ehk valmidus, mis määrab asjade ja isikute toimimist (nt valage tsemendist alus - kestab kauem, piimast saab (teha) (tehakse) juustu, laps käib juba ja oskab rääkida). Sellele tuginebki realiseeritavushinnang: kõneleja peab oma teadmiste, kogemuste ja oletuste põhjal midagi või kedagi potentsiaalselt võimeliseks/võimetuks midagi tegema, sh ennast realiseerima. See teadmine annab kõnelejale võimaluse manipuleerimiseks, k.a iseendaga, et adressaati oma tahtele allutada. Kõikidel elus ja elututel objektidel on valmidus aktiivsuseks, üleminekuks ühest seisundist teise, mis olenevalt tingimustest võivad saada reaalsuseks või olla mittereaalsed. Elusa objekti valmidus eeldab reaalseid või potentsiaalseid oskusi ning reaalset või potentsiaalset tahet püüda neid rakendada vastavalt tunnetatud vajadustele - kas omast soovist või kellegi kolmanda tahtele alludes (nt ta valetab $\sim$ ta on võimeline (pole võimeline) valetama, ma olen valmis lahkuma $\sim$ ma lahkun, Rain oskab (ei oska) laulda, ta sai (suutis) küsimustele vastata, ta oli võimeline küsimustele vastama, Inga mängib malet, ta tantsib päris hästi (halvasti), Ants mõtleb selgelt, Mari on meister puidust nikerdama, tüdruk käitus targalt, mul ei ole (ei tule) und, töö käib üle jõu, mind tõmbab tema poole, nad vajavad inimeste lähedust, on hädavajalik teada saada). Elutute objektide rakendatavus põhineb nende omadustel, millega tuleb / tuleks / on soovitatav arvestada (nt $u k s e d$ sulguvad automaatselt, termovaht parandab maja sisekliimat, penoplast rikub puitmaja, niiskus põhjustab allergiat, päikeseenergiast saab elektrit, seda raamatut (see raamat) on lihtne lugeda, hinnad tõusevad, abi pole loota).

Eespool kirjeldatud mõisted olen paigutanud süntagmaatilisele (sündmuse reaalsus, potentsiaalsus ja realiseeritavus) ning paradigmaatilisele teljele (sündmuse ettemääratus, toimumise objektiivsed ja subjektiivsed asjaolud). 
Niisiis on modaalhinnangu aluseks nähtused ja sündmused, asjad ja isikud ning nende toimimine (mõju-toime, tegutsemine-tegemine, talitus, toiming-tegevus-tegu) ehk asjade tegelik seis, mis võib olla 1) reaalne/võimalik, mittereaalne/mittevõimalik või potentsiaalselt võimalik/mittevõimalik ja 2) reaalselt teostatav/mitteteostatav või potentsiaalne. Sellest olenevalt, kas kõneleja arvates on miski ette määratud (determineeritud), saanud tavaks ja normeeritud, tingitud objektiivsetest asjaoludest ning (häda)vajalik või on tingitud subjektiivsest tahteavaldusest, saab nähtusi ja sündmusi hinnata nende reaalsuserealiseeritavuse skaalal.

Ettemääratud reaalsed ja realiseeritavad nähtused on paratamatud (nt kevadele järgneb suvi, nõgesed kõrvetavad), mittereaalsed ja mitterealiseeritavad nähtused ei toimi, nende olemasolu on võimatu (nt roomajad ei lenda, emu on lennuvõimetu lind, vesi ei kee (keeb) $80^{\circ} \mathrm{C}$ juures), potentsiaalselt toimivate nähtuste ilmnemise regulaarsus kujundab tendentse ja tavasid (nt kaugküte lülitatakse sisse tavaliselt oktoobris, mai alguses tähistatakse emadepäeva).

Objektiivsetest asjaoludest tingitud reaalsed nähtused tähistavad asjade tegelikku seisu (nt sügisel on ilmad külmad, päike käib madalalt, poisist on sirgunud noormees), reaalset võimalikkust lähiajal teoks saada (nt homme tuleb vihma, kleit saab valmis, varsti koidab, ta hakkab minema, juba asutavad end teele) ja lubatavust (võite vabalt tegutseda, suitsetamine lubatud/keelatud). Millegi (häda)vajalikkus tuleneb reaalsetest objektiivsetest nõuetest ja vajadustest (nt pesu peab olema homseks kuiv, õpikuid on vaja hoida, last tuleb kasvatada). Objektiivsed asjaolud tingivad ka potentsiaalselt võimalikke nähtusi (nt poiss näis kahevahel olevat, vastus tundub kahtlane, sellest raamatust võib saada bestseller, temast võib tulla hea ajakirjanik, kujutan ette, et sellest saab hea loo), mis võivad saada realiseeritud ja realiseeruda (nt pakettaknaid saab (annab) parandada, toiduained säilivad talvistes tingimustes hästi; ettevaatust, uksed võivad sulguda automaatselt) või eksisteerivad passiivse võimalusena, s.t erinevate seisunditena (nt käed on surnud 'võimatu midagi teha', 'võimetus midagi teha', julgete päralt on tulevik 'potentsiaalne võimalikkus', 'potentsiaalne võimekus'). Objektiivsetest asjaoludest tingitud realiseeritavad nähtused võivad eksisteerida aktiivse võimalusena, mis tähistab elusa objekti valmidust eneseteostuseks või elutu objekti valmidust sihipäraseks kasutamiseks (nt ta jätab maha siinse elu ja suundub linna, ma kõlban ärimeheks, pommi saab käivitada ka mobiiltelefoniga). Objektiivsetest asjaoludest tingitud mittereaalsed, -realiseeritavad ja -realiseeruvad tegevused on võimatud ehk 
teisisõnu pole võimalikud (nt eespool sõitvaid autosid pole (on võimatu) udus näha, uksi ei saa (ei anna) sulgeda, tursunud aknad ei sulgu, ei lähe korralikult kinni).

Subjektiivsetest asjaoludest ja tahteavaldusest tingitud realistlikku soovi hinnatakse reaalse ja tegelikult realiseeritavana (nt materjalid olgu (peavad olema, peavad saama) trükivalmis nädala pärast; trükikoda täidab (saab täita) tellimuse tähtajaliselt; laske kätel käia, sellega on kiire). Ebarealistliku soovi täitumist hinnatakse mittereaalse, tegelikult mitterealiseeritava ja kokkuvõttes võimatuna (nt kingi mulle tähed taevast, anna talle piiramatu voli teha kõike, mida hing igatseb). Subjektiivsetest asjaoludest ja tahteavaldusest tingitud potentsiaalsete nähtuste ilmnemise aluseks on püüdlus (näitab üles kannatlikkust, katsun mitte vahele rääkida), palve (lõpetage palun, kandke tema eest hoolt, lubage lahkuda), hoiatus (ärge külmetuge; vaata ette, tee on libe), soovitus (võiksite parem ära sõita, teen ettepaneku (soovitan) jalgsi minna, temaga ei tasu (pole mõtet) vaielda, annan sulle head nõu - ära vaidle vastu) jm kõnepragmaatikast tulenevad subjektiivsed vajadused, nagu üleskutse (ühendagem kõik jõud rahu nimel), ettepanek (lähme (koos) teatrisse, joome (tõstame klaasi) perenaise terviseks) ning keeld (ärge midagi puutuge) ja käsk (lahkuge viivitamatult, kästi lahkuda, ava uks, kuhugi sa ei lähe).

Modaalhinnangute väljendamiseks konkreetsel keelelisel tasandil kasutatakse erinevaid vahendeid: leksikaalseid (nt modaalverbid jt verbi leksikaalsemantilised rühmad, modaalsed abisõnad), leksikaalgrammatilisi (nt eesti keele perifrastilised verbid, perfektiiv-, imperfektiiv- ja aspektverbid; vene keele imperfektiivse ja perfektiivse aspekti verbid, ühe- ja kaheaspektilised verbid) ja morfosüntaktilisi (grammatiliste kõneviisi- ja ajavormide, aktiivi-passiivi funktsionaalne potentsiaal erinevates süntaktilistes struktuurides, k.a kinnistunud struktuurid jm). Seetõttu ei saagi üheselt väita, nagu oleks kõneviisi kategooria modaalsuse funktsionaalgrammatiline tuum. Bondarko (1990: $60 \mathrm{jj}$ ) kirjutab, et tegu on polütsentrilise (mitmetuumse) funktsionaalgrammatilise väljaga. Funktsionaalsemantilise välja alusel esile toodud modaalsuse liigitus tugineb omavahel seotud semantilistele määrangutele, samuti on omavahel põimunud nende keelelised väljendusvahendid, mis johtub interpretatiivsete predikatiivsete kategooriate ja leksika koosmõjust lauses. Iga modaaltähenduse edastamisel kasutab kõneleja kindlaid keelelisi vahendeid, kombineerides neid valivalt. Üksikasjalikum lingvistiline analüüs näitab, millised kombinatsioonid on relevantsed, millised mitte. 


\section{Näiteid keelelistest piirangutest modaaltähenduste väljendamisel}

Modaaltähenduste edastamise relevantsed/mitterelevantsed väljendusvahendid võivad keeliti varieeruda, olla ühes keeles kesksed, teises perifeersed või mitte kasutatud. Järgnevalt mõned näited nii vene kui ka eesti keelele tuginedes.

\subsection{Paratamatuse väljendamine}

Paratamatuse spetsiifiliseks väljendusvahendiks vene keeles on infiniitlaused, mille struktuur, leksika ja morfosüntaks on tihedalt põimunud. Tegu on ekspressiivse värvinguga kinnistunud süntaktiliste kooslustega, kus verbi aspekti valik mõjutab modaaltähendust. Tavaliselt kasutatakse imperfektiivse aspekti vormi, kirjeldatavat sündmust interpreteeritakse paratamatuna: Быть войне великой > Будет великая война 'Tuleb suur sõda'; Быть беде > Будет беда 'Häda meile!' ning 'Tuleb suur häda ja õnnetus'; Быть дождю > Пойдёт дождь 'Tingimata hakkab sadama' ning 'Hakkab sadama'. Asendades verbi infiniitse vormi finiitsega, ei muutu mitte ainult süntaktiline struktuur ja moodustajate funktsioonid, vaid ka lause modaaltähendus: finiitvormiga kirjeldatakse eesolevat reaalset sündmust, ekspressiivne värving kaob.

Kui jaatava kõne infiniitlause asemel kasutada eitavat kõnet, siis on eelistatud perfektiivne aspekt. Samas edastatakse piiri ja lõppu tähistavate verbidega, nagu Судьбь не миновать 'Saatuse eest ei pääse / pole pääsu', vältimatuse tähendust, muudel juhtudel objektiivsetest asjaoludest tingitud võimatust midagi teoks teha, nt В вагон не влезть 'Ei saa / ei mahu vagunisse', Tym не пройти не проехать 'Siit ei saa jalgsi ega autoga (vankriga) läbi'. Asendused modaalse abisõna ja perfektiivse aspekti infinitiiviga, nagu В вагон невозможно влезть 'Vagunisse pole võimalik / on võimatu siseneda' ja Тут невозможно пройти 'Siit pole võimalik / on võimatu läbi saada', säilitavad modaaltähenduse, kuid vene keele infiniitlausele omane ekspressiivne värving kaob. Koos eitussõnaga нельзя 'ei tohi, ei saa, ei või' kasutatakse reeglipäraselt imperfektiivse aspekti infinitiivi, nt Вася, нельзя жить таким Вася, таким жить нельзя 'Vasja, ei saa / ei tohi / ei või niimoodi elada Vasja, niimoodi elada ei saa / ei tohi / ei või', s.t on välistatud, pole normaalne. Inversiivne sõnajärg rõhutab kõneleja väljendatud mõtet. Perfektiivset aspekti kasutatakse harvem, see on seotud nihetega modaaltähenduses, põhjuseks aspektivormi varieerumine, nt Его нельзя 
назвать писателем 'Teda ei saa / pole võimalik nimetada kirjanikuks', s.t ei ole õige, õiglane nimetada kirjanikuks.

Niisiis on vene keeles paratamatuse väljendamise olulisim keelevahend infiniitlause - spetsiifiline kinnistunud ekspressiivse värvinguga struktuur, kus verbi aspekti varieerumine täpsustab tähendusnüansse (nt vältimatus ja normivastasus) või seob paratamatuse tähenduse teiste modaalhinnangutega (nt reaalne võimalikkus). Infinitiivi sünonüümne asendus modaalse liitpredikaadiga võib muuta lause modaaltähendust (nt paratamatus $>$ reaalne võimalikkus), neutraliseerub ka ekspressiivne värving. Et infiniitlaused kuuluvad vene keele spetsiifiliste nähtuste hulka (pole ülejäänud slaavi keeltes arenenud) ja nende tähendus sõltub suuresti kitsamast kontekstist või terviktekstist, siis aitavad tõlkevasted avada infiniitlausete funktsionaalsemantilist potentsiaali - eriti võrreldes nende keeltega, kus on olemas rikkalik modaalsõnavara, nagu eesti, soome või saksa keel. Ekspressiivsete varjundite kadu on peaaegu alati paratamatu, kuid olenevalt kontekstist annab alati leida võimalusi tõlkekadude kompenseerimiseks sihtkeeleomaste vahenditega (nt Бblmь беде $>$ Будет беда 'Häda meile!' ning 'Tuleb suur häda ja viletsus').

\subsection{Tendentsi väljendamine}

Tendentsi tähendus on seotud üldise väitega, et miski on potentsiaalselt reaalne/mittereaalne ja potentsiaalselt realiseeritav/mitterealiseeritav. Tendentside kirjeldamisel on reaalsuse ja realiseeritavuse hinnangud põimunud, seda kajastab ka keelevahendite valik ja nende võimalikud kooskasutusmallid. Tendentsi väljendamise relevantsed tunnused on 1) semantilise subjekti konkreetsus/abstraktsus (määratus/ määramatus), aktiivsus/passiivsus, eksplitsiitsus/implitsiitsus ning 2) verbi tegevuse abstraktsus (pidevalt või perioodiliselt korduv tavaline tegevus), ajaline piiritlematus (kõikaegsus).

Eksplitsiitse, konkreetse ja potentsiaalselt aktiivse subjektiga (enamasti ainsuse 1., 2. ja 3. isik, ka elutut ja elusat referenti markeerivad substantiivid) on seotud püüdlused ja suunitlused, mille seos paratamatuse tähendusega ilmneb ettemääratuse ja vältimatuse vahendusel. Vene keeles on verbide valik sel juhul leksikaalgrammatiliselt piiratud: enamasti kasutatakse imperfectiva tantum verbe стремиться 'püüdlema' (стараться 'pü̈̈dma'), влечься 'tõmbama kellegi-millegi poole', 'tõmbuma', тянуться 'püüdma', 'püüdlema', 'tõmbuma', рваться 'kippuma', 'püüdma', 'püüdlema', тяготеть 'ligi tõmbuma', 'ligi tõmbama' jm; samuti kinnistunud verbi-substantiivi ühendeid, nagu ucnbl- 
тыввать (питать, чувствовать) тяготение (тягу, пристрастие, жажду, аппетит, влечение) к чему 'tõmmet tundma', 'tõmbuma', 'janunema'; teadus- ja ametikeelele omaseid väljendeid, nagu вырисовывается линия что делать 'joonistub välja suund', имеется уклон во что 'on kalduvus' (установка на что 'hoiak, suund'), прослеживается направление (направленность, настроенность, ориентация) на что, что делать 'on jälgitav suund, suundumus, orientatsioon' jne. Näiteks: Я стараюсь жить по совести 'Mina püüan südametunnistuse järgi elada'; Его режиссёрская активность почти всегда устремляется во внутрь 'Tema lavastajaaktiivsus on peaaegu alati sissepoole suunatud', Растение тянется к солниу 'Taim sirutab end (sirutub) päikese poole'. Kirjeldatakse konkreetsete isikute, nende tegemiste ja nähtuste tavapärast toimimist, mis võib olla seaduspärane (determineeritud) või pika aja vältel objektiivselt välja kujunenud, ning iseloomustatakse elutu ja elusa subjekti valmidust aktiivselt toimida.

Eksplitsiitse, abstraktse ja potentsiaalselt aktiivse subjekti korral (enamasti mitmuse 3. isik, abstraktsed substantiivid, substantiveeritud adjektiivid) toonitab mitmuse vormi kasutus subjekti kõiksust, teatud määramatust. Seda toetab imperfektiivse aspekti vormi kasutamine usuaalses tähenduses. Tegevuse pidevat tavapärast kulgemist aitavad toonitada lause üldlaiendid, nt ajamäärused, nagu всегда 'alati', каждый вечер 'igal õhtul', не раз 'mitte ühel korral' jm: Собаки имеют способность ульбаться 'Koertel on võime (Koerad oskavad, suudavad) naeratada', В горы уходят отважные 'Kartmatud lähevad mägedesse', Сильный всегда влечётся к сильному 'Tugevat tõmbab tugeva poole'. Tulemuseks on aforismid või aforisme meenutavad sõnastused, milles väljendatakse tõdemust kellegi potentsiaalsest võimest (kalduvusest) midagi teha, kirjeldades seda kui tendentsi.

Eksplitsiitse passiivse subjekti (ainsuse ja mitmuse 1., 2. ja 3. isik akusatiivi või daativi vormis) korral on verbivalik leksikaalsemantiliselt kitsas ja morfosüntaktiliselt piiratud: korduvad imperfektiivse aspekti verbid манить 'ligi meelitama, ahvatlema, kutsuma', тянуть 'ligi tõmbama', 'meelitama', влечь 'kaasa tõmbama, kiskuma'. Keegi või miski määramatu tõmbab, kisub semantilist subjekti kaasa, ahvatleb teda pidevalt midagi tegema. Näiteks: Его всё больше стало тянуть на практическую работу 'Teda hakkas aina rohkem kiskuma praktilise töö poole', По вечерам его манило за город 'Õhtuti ahvatles teda miski linnast välja minema'. Semantiline subjekt pole ei reaalselt ega potentsiaalselt aktiivne, pole ka teada tema valmidus tegutseda jm ning on seetõttu määratud passiivsena. Kirjeldatakse tendentsi subjekti seisundis: teda tõmbab ja ahvatleb miski määratlematu. 
Implitsiitne, abstraktne ja potentsiaalselt aktiivne subjekt on metafoorne. Selle väljendamiseks kasutatakse ainsuse 1. pöörde asemel ainsuse 2. pöörde vormi, nt Целовать такую - сплошное удовольствие, с ума сойдёшь 'Suudelda niisugust on lausa nauding, arust võid ära minna'; Есть много слов, которые произносишь по привычке 'On palju sõnu, mida tood harjumusest kuuldavale'. Nende lausete modaalset põhitähendust täpsustab verb: perfektiivse aspekti korral on tegu potentsiaalse korduvuse värvinguga, imperfektiivse aspekti puhul harjumuspärase tavalise nähtuse kirjeldamisega. Mõlemad viitavad suundumuse või tendentsi olemasolule. Grammatilist metafoori (ainsuse 2. pöörde vorm 1. pöörde asemel) saab sünonüümselt asendada modaaladverbi ja infinitiiviga, nt $c$ ума сойдёшь > с ума можно сойти 'arust võid ära minna' ja 'arust võib ära minna'; произносишь по привычке > можно произносить по привычке 'tood kuuldavale harjumusest' ja 'saab kuuldavale tuua harjumusest'. Selles on näha modaalhinnangute põimumist - tendentsi vaadeldakse reaalselt toimiva ja realiseeritavana.

Ilmplitsiitset, määramata ja passiivset subjekti kasutatakse üldistustes, nt Каждый год делается много изобретений 'Igal aastal tehakse palju avastusi'. Igasuguse üldistuse taga võib näha tendentsi. Seda soosib imperfektiivse aspekti verbide kasutus, lause üldlaiendid konkretiseerivad tegevuse ajalist korduvust (каждый год, ежедневно), määrasõnad (много, всё больще) nähtuse ilmnemise intensiivsust jne. Nende tingimuste koosmõjus lisandub tähendusnüanss 'on tavaks saanud, tavakohane, iseloomulik', nt В таких случаях обвиняются родители (принято обвинять родителей) 'Sellistel juhtudel süüdistatakse (on tavaks, kombeks / on tava, komme süüdistada) vanemaid'. Seda tüüpi üldistavaid lauseid esineb sageli ajalehe- ja teaduskeeles, populaarteaduslikes tekstides. Tähenduskomponent 'tavapärane, iseloomulik' seob omavahel potentsiaalselt reaalse/mittereaalse ja realiseeritava/mitterealiseeritava sfäärid, nt Были намечены направления дальнеймего развития 'Olid maha märgitud edasise arengu suunad'.

Niisiis on tendentsi väljendamise keelelistel vahenditel kindlad omavahelise kombineerumise võimalused ning leksikaalsemantilised ja morfosüntaktilised piirangud. Tendentside kirjeldamise aluseks on semantilise subjekti leksikaalgrammatiline iseloomustus, millega käsikäes käib verbide leksikaalsemantiline piiratus ning aja- ja aspektivormide valik. Adverbiaalsete laiendite lisamine toonitab sündmuse või nähtuse korduvust, regulaarsust, tavapärasust, iseloomustades selle ilmnemise määra ja viisi. 


\subsection{Oletuse väljendamine}

Kolmanda näite puhul lähtun eesti keelest. Küsimus on kaudses kõneviisis, mille üheks funktsiooniks on väljendada oletust, kuna kõneleja kahtleb vahendatava väite tõeväärtuses. Samas pole oletus modaalsuse funktsionaalsemantilises tüpoloogias esile tulnud. Vene keeles kaudne kõneviis puudub ning oletuse edastamiseks kasutatakse leksikaalseid ja süntaktilisi vahendeid: pooleldi tuhmunud tähendusega tunde-, kõne- ja mõtteverbe olevikus mitmuse 3. pöördes ja minevikus mitmuse vormis. Tegevussubjekt on implitsiitne, impersonaalne ja abstraktne, selle all mõistetakse kedagi, kuid pole teada, keda täpselt, või on tegu nimetu massiga (kõik). Need kaks asjaolu (verbide mittetäistähenduslikkus ja tegevussubjekti implitsiitsus) tingivad selle, et pealause, milles tunde-, kõne- ja mõtteverbe kindlas grammatilises vormis kasutatakse, on süntaktiliselt ja semantiliselt sõltuv võrdlev-identifitseeriva sidesõnaga (nt точно, словно, (как) будто, якобы 'justkui, nagu') algavast kõrvallausest, nt Говорят, будто дом пустой 'Räägitakse, et (justkui, nagu) maja olevat tühi'. Venekeelne tõlkevaste väljendab samuti oletust, sest kõneleja kahtleb vahendatava väite tõeväärtuses. Kahtluse rõhutamiseks võib lisada kliitikuid, nagu мол, дескать 'näe, ena, vaat' (nt Говорят, мол, будто дом пустой 'Räägitakse näe, et (justkui, nagu) maja olevat tühi', mida saab lauses vabalt ümber paigutada.

Niisiis on mõlemas keeles vahendatud teate (väite) tõeväärtushinnanguks kasutatud erinevaid keelelisi vahendeid, kuid tõeväärtushinnangu aluseks on lause tekstipragmaatilised funktsioonid. Seetõttu ei kajastugi oletus modaalsuse funktsionaalsemantilises väljas: tõeväärtushinnang väljendab kõneleja seisukohta ega kuulu predikatiivse modaalsuse alla. Siin on näha funktsionaalsemantilise välja kasulikkust eri liiki hinnangute piiritlemisel. Samalaadselt tähistavad tõeväärtushinnangut ka näiteks erinevat päritolu modaaladverbid (ilmselt, tõenäoliselt, arvatavasti, vist (homme tuleb ilmselt (arvatavasti, tõenäoliselt, vist) päikesepaisteline ilm 'завтра, по всей вероятности (вероятно), будет солнечная погода', mis jäävad samuti predikatiivse modaalsuse väljendusvahendite hulgast välja.

Teine võimalus oletuse väljendamiseks vene keeles on mittetäistähenduslikud tunde-, kõne- ja mõtteverbid, nt предполагать 'eeldama, oletama', строить догадки 'oletama', гадать 'oletama, mõistatama, arvama', соображсать 'vaagima, mõtlema', прикидывать 'ligikaudselt määrama, oletama', казаться 'näima, tunduma', чудиться 'tunduma, näima, paistma', грезиться 'kangastuma, viirastuma', мыслиться 
'tunduma, näima, paistma', представляться 'vaimusilmas ilmuma, kangastuma', мниться 'näima, tunduma', считаться 'lugema, pidama', слыть 'pidama' jne. Neid verbe kasutatakse samamoodi pealauses, mis sõltub süntaktiliselt ja semantiliselt kõrvallausest, kuid erinevalt tõeväärtushinnangu väljendamisest esineb verb koos eksplitsiitse datiivse semantilise subjektiga või implitsiitse konkreetse isikuga, keda saab identifitseerida verbi grammatilise vormi alusel. Kõrvallause algab samuti võrdlev-identifitseeriva sidesõnaga, selle tähendust saab modifitseerida бbl-partikliga, nt если был, вроде бы, словно бы jt (võimalik ka tõeväärtushinnangu puhul). Pea- ja kõrvallause verb on sel juhul tavaliselt kindlas või tingivas kõneviisis. Näiteks: Мне кажется, (что) они опаздывают 'Mulle tundub, et nad hilinevad / jäävad hiljaks' - reaalne võimalikkus; Ему чудилось, будто / как будто (что) он был дома и ... 'Talle näis, nagu oleks ta kodus olnud ja ...' potentsiaalne võimalikkus, Промолчал бы - всё было бы в порядке 'Olnuks vait, oleks kõik korras olnud' - subjektiivsetest asjaoludest tingitud mittevõimalikkus ehk võimatus; Если бы он промолчал об этом, то всё было бы в порядке 'Kui ta olnuks vait / oleks vait olnud, siis oleks kõik korras olnud' - subjektiivsetest asjaoludest tingitud mittevõimalikkus ehk võimatus. Toodud näidete varal tuleb ilmsiks seos modaalsuse funktsionaalsemantilise välja paradigmaatiliste tunnuste (determineeritus - tingitus objektiivsetest asjaoludest - tingitus subjektiivsetest asjaoludest) ja süntagmaatiliste tunnuste (sündmuse reaalsuse/realiseeritavuse hinnang) vahel. See tunnuste ristumine toob selgelt esile erinevuse modaalhinnangu ja pragmaatilise hinnangu vahel ning seletab tõeväärtushinnangu ambivalentsust.

Oletamine on kognitiivne tegevus, mis tugineb võrdlemisele. Selle põhjal otsustab kõneleja millegi sarnasuse üle või teeb oletusi millegi sarnanemisest (nt точно я прожил большую жизнь 'justkui oleksin pika elu läbi elanud'), kandes üle teadvuses kangastunud pilte asjade reaalsele seisule (nt Сижу и вдруг чувствую, точно мне провели рукой по спине 'Istun ja tunnen äkki, nagu oleks keegi käega üle selja tõmmanud'). Ka tõeväärtushinnangu puhul kasutab inimene sama protseduuri, kuid üks asi on hinnata asjade seisu ja teine asi see, mida me sellest arvame ja kuivõrd tõeseks peame.

\section{Kokkuvõte}

Funktsionaalsemantiline väli on kahtlemata universaalne vahend liigituste loomiseks, sest välja konstrueerimise aluseks on loomulikud 
mõisteseosed, mitte grammatilised kategooriad ja lausesüntaks. Semantikast lähtudes saab võrrelda põhimõtteliselt mida tahes, nii ühe keele kasutust kui ka mitut keelt, teha keeletüpoloogilisi järeldusi jm. Mõistepesadel ja võimalikel seostel nende vahel on selles keskne roll, mis leiab kajastust ka leksikaalsete üksuste morfosüntaksis (vt 3. ptk, Näiteid keelelistest piirangutest modaaltähenduste väljendamisel).

Mõisteseoste leidmiseks ja kirjeldamiseks saab kasutada erinevaid meetodeid. Tulemusi võib interpreteerida eri tasanditel, erinevates aspektides ja erinevate teooriate valguses, kuid arvestusega, et rakendatud meetodid oleksid sobivad ning annaksid adekvaatse tulemuse. Semantiliste määrangute puhul sobib kõrvuti arvutilingvistiliste meetodite ja vahenditega ka siinses uurimuses kasutatud lingvistiline lähenemine: tautoloogiliste (suletud) ringide leidmine sõnade tähenduskomponentide vahel nii ühe leksikaalsemantilise rühma piires kui ka mitme leksikaalsemantilise rühma võrdluses, nii ühe keele alusel kui ka mitme keele võrdlemisel. Tähenduskomponentide lähedus-kaugus on aluseks semantilistele hierarhiatele, määrab leksikaalsemantilis(t)e rühma(de) piire, võimaldab kirjeldada leksikaalsemantilisi mikrovälju ning neid omavahel siduda. Mõisteseoste üldistamiseks kasutatud dialektilise loogika seadused aitavad leida kirjeldatava objekti olulisi tunnuseid, mille paigutamine süntgmaatilisele ja paradigmaatilisele teljele võimaldab erinevate tunnuste ristumisel esile tuua semantilisi tüpoloogiaid. See hierarhiline struktuur sobib objekti süsteemse esituse funktsionaalsemantiliseks aluseks.

Samas pole juhuslik, et mingid modaal- ja tõeväärtushinnanguga seotud tähendused jäävad semantilisest tüpoloogiast välja, näiteks oletus. Eespool kirjeldasin, et oletamine on võrdlusel põhinev kognitiivne tegevus ehk tunnetusprotsessi osa. Seevastu modaaltähenduste funktsionaalsemantiline tüpoloogia tugineb millegi reaalsuse/realiseeritavuse hinnangule. Iseasi muidugi, millisena me saadud ettekujutuse põhjal asjade reaalset seisu hindame (nt reaalne-võimalik-mittevõimalik) ning mida me sellest arvame (nt hea/halb), kuivõrd tõeseks peame. Siit tulenevad tõeväärtushinnangu ambivalentsus ja tekstifunktsioonid.

Sõnade keelelistest tähendustest tuletatud semantiline tüpoloogia koondab ja rühmitab kõige loomulikumal viisil relevantseid keelekasutusmalle, mida on ühe või teise tähenduse väljendamiseks tavaliselt vaja (vt 3. ptk, Näiteid keelelistest piirangutest modaaltähenduste väljendamisel). Leksikaalsete ja morfosüntaktiliste vahendite valik ning kombineerumine võib olla üpris keeruline, modaalsed ja pragmaatilised tähendused on sedavõrd põimunud ekspressiivsete värvingute ja erinevate tekstifunktsioonidega (vt tendents), et arusaamiseks läheb vaja 
avarat konteksti või tõlget (nt paratamatuse väljendamine vene keele infiniitlausega).

Keeliti esineb modaaltähenduste edastamisel osalist või täielikku lahknevust (vt paratamatus, oletuse väljendamine), analoogiat (vt tendents) ja kokkulangevusi. Keelesisese sünonüümse varieerumise abil annab kindlaks teha modaaltähenduste (osalist) kattuvust, omavahelisi seoseid, uute tähendusnüansside ilmnemist jm. Keeltevahelise varieerumise puhul on üheks seletuste leidmise võimaluseks tõlkevasted, mis toovad esile ühe keele varjatud tähendusi ja semantilist kihistumist (nt vene keele infiniitlausete peidetud tähenduste eksplitsiitsed väljendusvahendid eesti keeles). Kui aga võrrelda ühtsel semantilisel alusel valitud tõlkevasteid, siis saab suure tõenäosusega väita, et need peegeldavad keeltevaheliste seoste olemust. Siit sünnib kasu nii keeleõppes kui ka tõlketegevuses, kuna lähte- ja sihtkeele vaheline sümmeetrilisus ning analoogiaseosed hõlbustavad sihtkeele tunnetamist ja mõtestamist.

\author{
Aadress: \\ Pille Eslon \\ Digitehnoloogiate instituut \\ Tallinna Ülikool \\ Narva mnt 25 \\ 10120 Tallinn \\ E-post: pille.eslon@tlu.ee
}

\title{
Elektroonsed keeleressursid
}

Fraseologismide elektrooniline alussõnastik: http://www.folklore.ee/justkui/sonastik/. Vaadatud 12.09.2016.

Eesti keele tasakaalus korpus: www.keeleveeb.ee. Vaadatud 12.09.2016.

Eesti keele tesaurus: http://www.filosoft.ee/. Vaadatud 12.09.2016.

Vene kirjakeele korpus: www.ruscorpora.ru/. Vaadatud 12.09.2016.

\section{Kirjandus}

Bondarko, Aleksandr (1983) Prinzipy funkcional'noj grammatiki i voprosy aspektologii. Leningrad: Nauka.

Bondarko, Aleksandr (1990) “Modal'nost'. Vstupitel'nyje zamechanija". In Aleksandr Bondarko, toim. Teorija funkcional 'noj grammatiki: Temporal'nost'. Modal'nost', 59-67. Leningrad: Nauka. 
Bondarko, Aleksandr (1992) “K probleme sootnoshenija universal'nyh i idioetnicheskih aspektov semantiki: interpretatsionnyj komponent grammaticheskih znachenij”. Voprosy jazykoznanija 3, 5-20.

Bondarko, Aleksandr (2002) Teorija znachenija v sisteme funktsional'noj grammatiki. Moskva: Jazyki slav'anskoj kul'tury.

EKG II = Erelt, Mati, Reet Kasik, Helle Metslang, Henno Rajandi, Kristiina Ross, Henn Saari, Kaja Tael ja Silvi Vare (1993) Eesti keele grammatika II. Süntaks. Lisa: kiri. Tallinn: Eesti Teaduste Akadeemia Keele ja Kirjanduse Instituut.

EKSS $=$ Eesti keele seletav sõnaraamat . Kättesaadav aadressil: www.eki.ee/dict/ekss/. Vaadatud 12.09.2016.

Erelt, Mati (2013) Eesti keele lauseõpetus. Sissejuhatus. Öeldis. (Tartu Ülikooli eesti keele osakonna preprindid 4.) Tartu: Tartu Ülikool.

Eslon, Pille (1998) “Opyt semanticheskoj tipologii modal'nostej”. Tipologija. Grammatika. Semantika, 330-337. Sankt-Peterburg: Nauka.

Eslon, Pille (2006) “Analoogiast keelte kõrvutamisel”. Keel ja Kirjandus 1, 15-24.

Eslon, Pille ja Ants Pihlak (1991) Vid i vrem'a. Tallinn.

Eslon, Pille ja Katre Õim (2010) "Objektikäände kasutamisest sageduse ja markeerituse seisukohalt". ESUKA - JEFUL 1-2, 69-89.

Habicht, Külli ja Ilona Tragel (2014) "Verbiga saama väljendatud leksikaalsed kategooriad ja konstruktsioonid". Keel ja Kirjandus 11, 826-844.

Haspelmath, Martin (2003) "The geometry of grammatical meaning: Semantic maps and cross-linguistic comparison". In Michael Tomasello, ed. The new psychology of language, vol. 2. Mahwah, NJ: Lawrence Erlbaum, 211-242.

Jevgenjeva (1985) = Slovar' russkogo jazyka. Anastasia Jevgenjeva, toim. Kd. 1-4. Moskva: Ruskij jazyk.

Jevgenjeva $(2003)=$ Slovar' sinonimov russkogo jazyka. Anastasia Jevgenjeva, toim. Kd. 1-2. Moskva: Astral'.

Kangasniemi, Heikki (1992) Modal Expressions in Finnish. (Studia Fennica. Linguistica 2.) Helsingi: Suomalaisen Kirjallisuuden Seura.

Kehayov, Petar (2004a) "Eesti keele evidentsiaalsussüsteem mõne teise keele taustal. Morfosüntaks ja distributsioon”. Keel ja Kirjandus 11, 812-829.

Kehayov, Petar (2004b) "Eesti keele evidentsiaalsussüsteem mõne teise keele taustal. Semantika". Keel ja Kirjandus 12, 895-914.

Kehayov, Petar (2008) An Areal-Typological Perspective to Evidentiality: the Cases of the Balkan and Baltic Linguistic Areas. (Dissertationes Linguisticae Universitatis Tartuensis 10.) Tartu: Tartu University Press.

Klettenberg, Reet (2007) "Permissiivkonstruktsioonidest 17. ja 18. sajandi eesti kirjakeeles". In Csepregi Márta, Virpi Masonen, toim. Budapest. Grammatika és kontextus: Grammatica \& contextus. Budapest 2004, 133-145.

Luuk, Erkki (1999) “Tähenduse lineaarne ja hierarhiline struktuur”. Akadeemia 8, 1630-1660.

Luuk, Erkki (2008) “Semantilised tasandid ja semantilised primitiivid". Keel ja Kirjandus 12, 949-967.

Luuk, Erkki (2010) "Struktuuride nimisõna/verb ja lingvistiline predikaat/argument evolutsioon". Keel ja Kirjandus 6, 407-418. 
Mandra, Katrin (2007) "Deontiline modaalsus poliitikute arvamusartiklites". Keel ja Kirjandus 3, 178-193.

Metslang, Helle ja Hannu Tommola (1995) “Zum Tempussystem des Estnischen”. In Rolf Thieroff, ed. Tense systems in European languages II. (Linguistiche Arbeiten 338.) Tübingen: Niemeyer, 229-326.

Orav jt 2011 = Heili Orav, Kadri Kerner ja Sirli Parm (2011) "Eesti Wordnet'i hetkeseisust”. Keel Ja Kirjandus 1, 96-106.

Orav, Heili ja Kadri Vider (1998) “Sõna tasandilt mõiste ruumi”. Keel ja Kirjandus 1, $57-64$.

Russkaja grammatika (1980) = Russkaja grammatika . Natalja Švedova, toim. Kd. 1-2. Moskva: Nauka.

Tamm, Anne (2012) Scalar Verb Classes. Scalarity, Thematic Roles, and Arguments in the Estonian Aspectual Lexicon. (Biblioteca di studi di filologia moderna 14.) Firenze: Firenze University Press.

Tragel, Ilona (2001) "Eesti saama ja võima ning soome saada ja voida. Tähendused ja vastavused kognitiivse grammatika vaatenurgast”. Keel ja Kirjandus 2, 99-110.

Tragel, Ilona ja Ann Veismann (2008) "Kuidas horisontaalne ja vertikaalne liikumissuund eesti keeles aspektiks kehastuvad?". Keel ja Kirjandus 7, 515-530.

Uuspõld, Ellen (1989) "Modaalsusest ja modaalsest predikaadist eesti keeles". Keel ja Kirjandus 8, 468-477.

Vaiss, Natalia (2004) Eesti keele aspekti väljendusvõimalusi vene keele taustal. Magistritöö. Tallinn: Tallinna Ülikool.

Van der Auwera, Johan and Vladimir Plungian (1998) "Modality's semantic map". Linguistic typology 2, 79-124.

Van der Auwera, Johan, Petar Kehayov and Alice Vittrant (2009) “Acquisitive modals". In Lotte Hogeweg, Helen De Hoop, Helen and Andrej Malchukov, eds. Crosslinguistic Studies of Tense, Aspect, and Modality. Amsterdam: Benjamins, 271-302.

Vider, Kadri (2001) "Eesti keele tesaurus - teooria ja tegelikkus". Sõna tänapäeva maailmas: Leksikograafiaseminar "Sõna tänapäeva maailmas". Leksikografinen seminari "Sanat nykymaailmassa". (Eesti Keele Instituudi toimetised 9.) Tallinn: Eesti Keele Instituut, 134-156.

Vider, Kadri ja Heili Orav (2005) "Estonian Wordnet and Lexicography”. In Henrik Gottlieb, Jens Erik Mogensen and Arne Zettersten, eds. Symposium on Lexicography $X I$. Tübingen: Niemeyer, 549-555.

Õim, Asta (1995) Sünonüümisõnastik. Tallinn: TA Eesti Keele Instituut.

Õim, Katre (2003) Võrdluste struktuurist ja kujundisemantikast. (Reetor 2.) Tartu: Eesti Kirjandusmuuseum Folkloristika osakond, Eesti Kultuuriloo ja Folkloristika Keskus.

Õim, Katre (2005) "Metafoori mõistmise mudelid: kategoriseerimine vs. võrdlemine". Akadeemia 8, 1751-1772.

Õim, Katre (2007) “Metafoor ELU ON TEEKOND ebaõnne-väljendites”. Mati Erelt ja Tiiu Erelt, toim. Emakeele Seltsi aastaraamat 52 (2006), 179-194. Tallinn: Emakeele Selts.

Õim, Katre ja Asta Õim (2011) "Eesti fraseoloogia leksikograafiline areng”. Keel ja Kirjandus 11, 842-862. 


\begin{abstract}
Pille Eslon: The functional-semantic field as the basis for classifying modal meanings and comparing languages. The functionalsemantic field is a universal means for object classification and comparison that can be used both within a single language and typologically. Because the field is constructed using natural links between concepts, and not grammatical categories or sentence syntax, it lends itself to establishing classifications, including a semantic hierarchy of modal meanings discussed in the article. It allows us to clarify and elaborate on certain complexities of the construct of language, e.g. the ambivalence of the value judgement of truth. In order to establish and describe the links between concepts within a functional-semantic field, current research has resorted to lexicographical sources, corpuses and grammars of the Estonian and Russian languages. For the construction of the field of modality, the method of tautologic or closed circles (in Latin: idem per idem) was used. The proximity or distance of the components of meaning allows for the description of the bounds of lexicosemantic groups, for construction of lexicosemantic micro-fields and for their integration. Generalisation of conceptual links is based on the laws of dialectic logic that helps to identify the significant features of the object. Placed on syntagmatic and paradigmatic axes, intersection of such features produces a structure that is suitable for creating modal classifications and for a systematic description of the object. The article highlights the fact that while expressing modal meaning, the Estonian and Russian languages make use of particular adjaceny patterns of lexemes, structures and syntactic structures that have limited lexicosemantic and morphosyntactic variability.
\end{abstract}

Keywords: functional-semantic field, modality, Russian, Estonian 